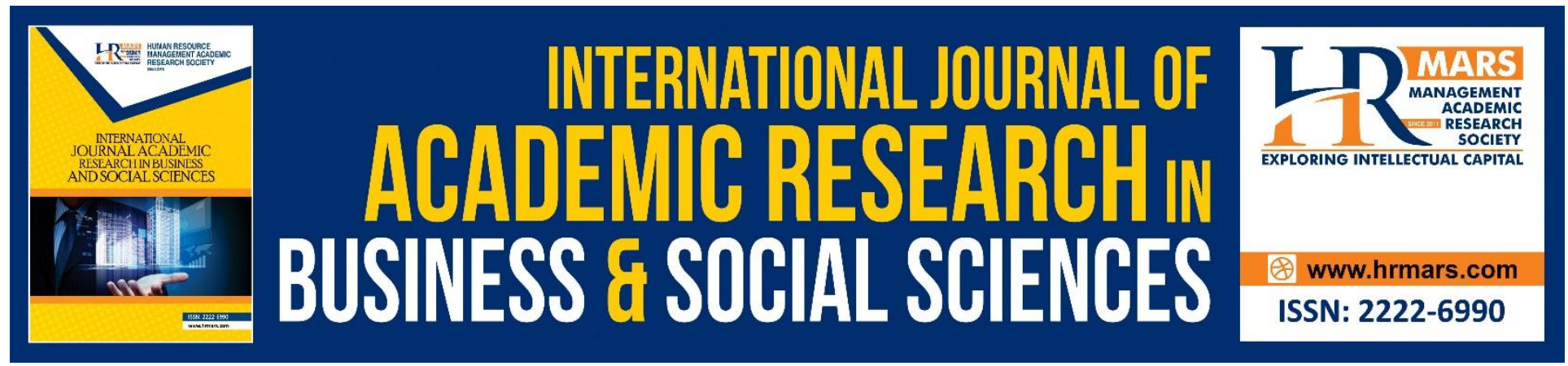

\title{
EA adoption in Malaysian Maritime Industry: A Conceptual Study and Future Direction
}

Norfadzilah Rashid, Affizah binti Mohamad Ghaffar, Mohd Zulkifli Mokhtar, Wan Nur Syahida Wan Ismail, Ahmad Shukri Yazid, Asyraf Afthanorhan

To Link this Article: http://dx.doi.org/10.6007/IJARBSS/v8-i11/5201

DOI: $10.6007 /$ IJARBSS/v8-i11/5201

Received: 13 Oct 2018, Revised: 29 Nov 2018, Accepted: 30 Dec 2018

Published Online: 31 Dec 2018

In-Text Citation: (Rashid et al., 2018)

To Cite this Article: Rashid, N., Ghaffar, A. binti M., Mokhtar, M. Z., Ismail, W. N. S. W., Yazid, A. S., \& Afthanorhan, A. (2018). E-Accounting adoption in Malaysian Maritime Industry: A Conceptual Study and Future Direction. International Journal of Academic Research in Business and Social Sciences, 8(11), 1421-1436.

Copyright: (C) 2018 The Author(s)

Published by Human Resource Management Academic Research Society (www.hrmars.com)

This article is published under the Creative Commons Attribution (CC BY 4.0) license. Anyone may reproduce, distribute, translate and create derivative works of this article (for both commercial and non-commercial purposes), subject to full attribution to the original publication and authors. The full terms of this license may be seen at: http://creativecommons.org/licences/by/4.0/legalcode

Vol. 8, No. 11, 2018, Pg. 1421 - 1436

Full Terms \& Conditions of access and use can be found at http://hrmars.com/index.php/pages/detail/publication-ethics 


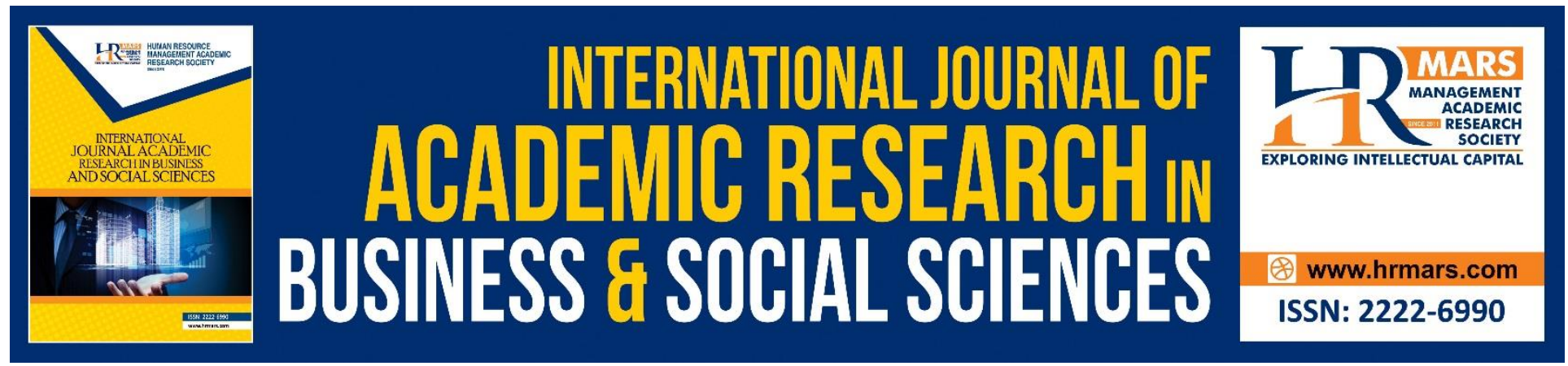

\title{
E-Accounting adoption in Malaysian Maritime Industry: A Conceptual Study and Future Direction
}

\author{
${ }^{1}$ Norfadzilah Rashid, ${ }^{2}$ Affizah binti Mohamad Ghaffar, ${ }^{3}$ Mohd \\ Zulkifli Mokhtar, ${ }^{4}$ Wan Nur Syahida Wan Ismail,. ${ }^{5}$ Ahmad Shukri \\ Yazid, ${ }^{6}$ Asyraf Afthanorhan \\ ${ }^{2,3,4}$ School of Maritime Business and Management, Universiti Malaysia Terengganu, 21030 \\ KualaTerengganu, Malaysia \\ 1,5,6Faculty of Economic and Management Sciences, Universiti Sultan Zainal Abidin, 21300 Kuala \\ Nerus, Malaysia
}

\begin{abstract}
The purpose of this conceptual paper is twofold; first to examine the factors affecting EA adoption in Malaysian Maritime Industry, second to study the effect of e-accounting adoption on firm performance. This paper proposed to investigate the factors influencing the e-accounting adoption in the technological, organizational, environmental and owner-manager contexts in order to provide wider perspective. Extending the model, this paper also perceives the importance of investigating the effect of e-accounting adoption on company performance. By applying this model in future empirical research, it is expected to reveal the determinants of the e-accounting adoption among the SMEs in the maritime industry while its effect on the firm overall performance of Malaysian maritime industry is expecting to give a clue to the industry for the role of e-accounting.
\end{abstract}

Keywords: E-Accounting, SMES, Performance, Maritime Industry

\section{INTRODUCTION}

Maritime industry is one of the important industries in Malaysia as Malaysia itself is a maritime nation. Malaysia has historically been one of the great maritime nations of the world with its strategic location along the Straits of Malacca and a globally connected shipbuilding business in Borneo. In the National Technology Foresight 2010 Report, maritime, under the transportation banner, was identified as one of the key focus areas to mobilize Malaysia's future economy. The First National Marine Industries Forum (1NMIF) held on 23 March 2010 produced the Malaysian 
Shipbuilding \& Ship Repair Industry Strategic Plan 2020 (SBSR 2020) and launched by the Honourable Prime Minister Dato' Sri Mohd Najib bin Tun Abdul Razak on 6 December 2011. He is confident that the maritime industry would thrust Malaysia as a nation that has the capabilities not only in the petroleum automotive industry but also in the venture of building high technology ships. The introduction of the SBSR 2020 during the Langkawi International Maritime and Aerospace Exhibition (LIMA) 2011 and acceptance of SBSR projects as Entry Point Project under the Economic Transformation Program (ETP) are evidence of the importance of the marine industry, especially in creating further growth towards achieving the nation's development aspirations. Malaysia has many advantages and features that can be leveraged upon to make it an internationally competitive oil and gas nation. This include strategic location along busy shipping routes, pro business policies, hydrocarbon resources, favorable maritime facilities and also impressive achievements in areas such as port operations, merchant shipping, offshore oil and gas, shipbuilding and ship repairing.

Referring to Malaysian Shipbuilding/Ship Repair Industry Strategic Plan 2020 (Malaysian Shipbuilding/Ship Repair Industry Strategic Plan 2020, 2011), it is estimated that by 2020, the shipbuilding / ship repair industry in Malaysia will contribute RM6.35 billion (USD2.01 billion) to the Gross National Income (GNI) (based on current uptrend of gross output, the estimated industry growth rate and employment growth rate for the next 10 years are $10 \%$ and $6 \%$ per annum respectively which the Gross National Income (GNI) contribution is based on a $5 \%$ average annual rate) and provide in excess of 55,500 jobs, along which the private sector investment is estimated to reach up to RM9.76 billion (USD3.09 billion), whilst the public sector investment required reaching RM144 million (USD45.57 million). Given the growing significance of the oil and gas industry, it will give advantage not just for domestic players, but also more widely for regional and international players. Malaysia oil and gas industry is expected to remain busy for the next few years with growing requirement for offshore support vessels to cater for increasing oil and gas activities (Malaysia Shipbuilding/Ship Repair Industry Report 2013/2014, 2013). Small and medium-sized enterprises (SME) in the maritime industry, an industry in which SME demonstrate higher-than-average innovation activity (Bass \& Siebert, 2007) seem to be the ideal vehicle to promote both goals - sustainable innovation-based economic growth and employment creation.

This paper will provide conceptual framework to enrich the ongoing discussion, focusing on innovation adoption in SMEs in the Malaysian maritime industry - one of the leading industries in the recent phase of globalization, an industry which underwent tremendous organizational changes during the last decade and due to the industry's relevance in innovation and for employment, a target industry for Malaysian's industrial policy. Malaysia shipbuilding / ship repair industry portal reported that for the year 2012 maritime industry generated RM7.34 billion in revenue, attracted RM0.42 billion in investment and provided more than 33,000 jobs opportunities. As most of the businesses in Malaysia are micro, small and medium, in our study 
INTERNATIONAL JOURNAL OF ACADEMIC RESEARCH IN BUSINESS AND SOCIAL SCIENCES Vol. 8, No. 11, Nov, 2018, E-ISSN: 2222-6990 @ 2018 HRMARS

we considered enterprises which either employ less 200 employees or have turnover of less than RM50 million (SME Annual Report 2012/2013, 2013).

Record keeping is very crucial in financial management of SMEs and failure of it will affect the overall firm performance. In implementing or managing a business, what to look for is profit. This profit is derived financial gain. To calculate the profit, the entrepreneur should have a record of business activity. Without a record or records of financial activity, only entrepreneurs can only estimate the amount of profits. Account is important because it aims to facilitate business. Regardless of small or large business, the role of business accounting systems is same. With the account, profit and loss business is clearly visible. Some entrepreneurs are not only do not know the exact amount of profit and loss but does not know directly whether their business profit or loss. Business's profit is considered when there is a surplus of sales or not.

Accounting information system (AIS) can help businesses, particularly SMEs to manage shortterm problems in areas such as costing, expenditure and cash flow, by providing information to support monitoring and control. It can also help SMEs operating in a dynamic and competitive environment, to integrate operational considerations within long-term strategic plans ( $N$. A. Ismail \& King, 2005). Although AIS users can now generate and use accounting information in a more strategic way, the revolution in information technology (IT) and information systems (IS) has also raised several issues that need to be carefully addressed, particularly in the context of SMEs. As SMEs require more information than larger firms to deal with higher uncertainties in competitive and market demand conditions, they also need to enhance their information systems and thereby increase their information processing capabilities to match their higher information requirements (N. A. Ismail \& King, 2005).

SMEs accounted for the majority of businesses in many countries in the world. The businesses have an important role in the economy of developed and developing countries as they create new business, increase employment opportunities, develop innovative product ideas, and raise productivity (Samujh, Twiname, \& Reutemann, 2012). Unfortunately, a study by Fatoki (Fatoki, 2012) found a high failure rate among SMEs, especially new SMEs operate. The main cause of failure among SMEs is correlated with poor management, particularly in the areas of financial management (Ademola, O, Olusuyi, \& Edun, 2013; Evans, Carlon, \& Massey, 2005; Mwakujonga \& Bwana, 2013) exposed a large number of SMEs' managers have abandon an important role of preparing and using financial information in decision making. As a result, they have been pursuing poor financial decisions which are regarded to be the main cause for poor performances and increase in failure rates of their undertakings. Specifically, SMEs are entities which do not have the onerous requirement of filing their financial statements with any regulatory body for the purpose of issuing financial instruments. These entities do not hold assets in any fiduciary capacity for a group of outside investors (banks, insurance entities, security brokers, funds, etc) but the owners, who usually are also managers. Lack of financial management which is poor record keeping is one of the SMEs collapse (Muchira, 2012) (Maseko \& Manyani, 2011). As the 
engine or back bone of economic growth, SME play an important role. One of the solutions is the e-accounting employment. However, some SMEs refuse the technology for many reasons such as cost and expertise issues.

Malaysian SMEs serve as a dynamic and integral part of the Malaysian Industrial Development. The strategic use of ICT among SMEs is seen as one of the key elements that ensure a significant difference in their effort for success. Few attempts have been made to study the usage of eaccounting, especially in the context of SMEs sized firms in Malaysia. This issue is important because results from previous studies focus on the implementation of accounting information system for an organization in general and multiple industry (Amelia, Fariha, \& Azliza, 2014). One of the key strategies to spur the development of the SBSR 2020 is by adopting new technologies including ICT. So, to conduct these well-established studies, researchers within the field needs to acquire a good understanding about the different factors affecting the adoption of e-accounting by organizations operating in different sectors such as the maritime sector and also the effect on firm performance.

Therefore, this conceptual study sought to investigate the factors influencing the e-accounting adoption in Malaysian maritime SMEs. Besides, this study also attempts to analyze the impact of using the e-accounting on the overall maritime firm performance.

\section{LITERATURE REVIEW}

\section{E-Accounting Adoption}

E-Accounting refers to Electronic Accounting, a term used to describe an accounting system that relies on computer technology for capturing and processing financial data in organizations [14, 15]. In the literature, more terms have been used to describe E-accounting (EA): Computer-Based Accounting System (CBAS) (Tijani \& Mohammed, 2013), Computerized Accounting System (CAS) [17-20], Computerized Accounting Information System (CAIS) [21, 22] and Accounting Information System (AIS) [23-25]. E-Accounting term is utilized by Amidu et al. [14], [15], Relhan [26], Soudani (Soudani, 2013), Velankar, Gupta, \& Garud (Velankar, Gupta, \& Garud, 2013) in their study. Stefanou (Stefanou, 2006) observed that although accounting information system does not require a computer to function, the computerization of the accounting function, the term AIS is used primarily to denote the computer-based AIS. In this study the term E- Accounting (EA) is used to refer to any accounting system that depends on ICT for performing its information system functions.

Accounting plays a critical role in the success or failure of contemporary business institutions. Accounting systems are responsible for recording, analyzing, monitoring and evaluating the financial condition of companies, preparation of documents necessary for tax purposes, providing information support to many other organizational functions, and so on. Prior to the advent of personal computers, businesses were limited to manual methods for keeping track of financial data. The manual accounting systems consisted of paper ledgers, typewriters and 
calculators (Tavakolian, 1995). Typewriters were used to type invoices and cheques, and all calculations were performed using calculators. However, with this system it was possible for errors to be introduced into the data since they could go undetected for quite some time. Like many other industries, the accounting industry changed with the arrival of personal computers. An e-accounting system is able to handle financial data efficiently, but the true value of an accounting system was that it was able to generate immediate reports regarding the company. Just select few menus in the system and financial report will be produced automatically and faster.

\section{E-accounting adoption determinants}

The diffusion of innovation theory (DOI) is a theory of how, why, and at what rate new ideas and technology spread through cultures, operating at the individual and firm level. It sees innovations as being communicated through certain channels over time and within a particular social system (Rogers, 1995). Based on the DOI theory at firm level (Rogers, 1995), innovativeness is related to such independent variables as individual (leader) characteristics, internal organizational structural characteristics, and external characteristics of the organization.

Meanwhile, the TOE framework (L.G. Tornatzky \& Fleischer, 1990) identifies three aspects of an enterprise's context that influence the process by which it adopts and implements a technological innovation; (a) Technological context describes both the internal and external technologies relevant to the firm; (b) Organizational context refers to descriptive measures about the organization such as scope, size, and managerial structure; (c) Environmental context is the arena in which a firm conducts its business-its industry, competitors, and dealings with the government. This framework as originally presented, and later adapted in IT adoption studies, provides a useful analytical framework that can be used for studying the adoption and assimilation of different types of IT innovation. It has a solid theoretical basis and the potential of application to IS innovation domains, though specific factors identified within the three contexts may vary across different studies.

Furthermore, this framework is consistent with the DOI theory, in which Rogers (Rogers, 1995) emphasized individual characteristics, and both the internal and external characteristics of the organization, as drivers for organizational innovativeness. These are identical to the technology and organization context of the TOE framework, but the TOE framework also includes a new and important component, environment context. The environment context presents both constraints and opportunities for technological innovation.

Therefore, we will utilize the DOI, and especially the TOE framework, because they are the only ones that are at the firm level (Oliveira \& Martins, 2011) to investigate the factors influencing the e-accounting adoption for Malaysian maritime SMEs. This framework has been used by (Wan 
INTERNATIONAL JOURNAL OF ACADEMIC RESEARCH IN BUSINESS AND SOCIAL SCIENCES Vol. 8, No. 11, Nov, 2018, E-ISSN: 2222-6990 C 2018 HRMARS

Ismail, 2014) when studied adoption of computerised accounting information system in Malaysian SMEs.

\section{Technological}

There are three dimensions in the technological context namely relative advantage, compatibility and complexity will be defined as technology adoption determinant in this study. They were selected because these characteristics were frequently found to be significant in IT / IS adoption in numerous empirical researches. In fact, these three innovation characteristics had the most consistent and significant relationship to innovation adoption compare to the other innovation characteristic.

Relative advantage. Relative advantage is defined as the degree to which an innovation is perceived as providing greater organizational benefits than the idea it supersedes or the status quo (Rogers, 1983). It is reasonable that organizations take into consideration the advantages that stem from adopting innovations (Wang, Wang, \& Yang, 2010). In sum, companies which perceive higher relative advantages in EA technology tend to be more likely to adopt the technology.

Compatibility. Compatibility is the degree to which an innovation is perceived as being consistent with the needs or the existing practices of the potential adopters (Rogers, 1983)(Louis G. Tornatzky \& Klein, 1982). High compatibility has been identified as a facilitator for innovation adoption (Wang et al., 2010). Their study's divulged that the compatibility was found to have a significantly positive effect on firm decisions to adopt innovation. Resistance to change may be an important issue on the implementation of any IS systems include EA ( Wang et al., 2010). Therefore, compatibility may be an important determinant of EA adoption.

Complexity. Complexity is the extent to which an innovation is perceived as relatively difficult to understand and use (Corrocher, 2003). Since complexity of an innovation can function as an inhibitor for successful implementation, it is usually negatively associated with adoption (Louis Tornatzky \& Klein, 1982). It may take users a long time to understand and implement the technology (Wang et al., 2010).

\section{Organizational}

There are three dimensions in the organizational context namely financial commitment, business/maritime cluster and technology competence will be defined as technology adoption determinant in this study. 
Financial commitment. Financial commitment is plays an important role for SMEs in determining adoption of IT / IS in their business (Alam \& Noor, 2009). It relates to the anticipated costs of using e-accounting. As any used of technology, EA associated with costs (even using the existing infrastructure is not cost free, as the employees have to learn new practices). Examples of EA implementation costs include administrative costs and training costs. Organizations that perceive the costs to be high will be reluctant to use e-accounting. Perceived implementation costs can be seen as a factor suggested by the DOI theory (corresponding to the complexity attribute of innovation). Limited financial resources compel owner/managers to be cautious about their investment and capital spending, thus, only SMEs having adequate financial resources would regard adoption of IS as a feasible project to undertake (James \& Thong, 1999) ( Thong \& Yap, 1995). In addition, it should be considered that along with the initial cost of computer hardware and software, other IS implementation expense including the cost of maintenance and the costs of taking expert professionals into service, and IS development and the post deployment costs should be undertaken by SMEs during different phases of IS adoption (Ghobakhloo, Arias-Aranda, \& Benitez-Amado, 2011). Therefore, EA adoption is also affected by the indirect costs of adoption such as the costs of human factors (e.g. training). In this regard, when owner/managers of SMEs (particularly SMEs of developing countries which usually suffer from severe financial constraints) (Ghobakhloo \& Tang, 2013) perceive EA costly to adopt, they are expected to be less committed to EA adoption.

Business / maritime cluster. Malaysian maritime industry cluster comprising three main sectors: ports and terminals, shipping services and ship industry (Othman, Bruce, \& Hamid, 2011). Ports and terminal sector include port operator, port engineering and logistics. Shipping services sector consist of sea transportation and communication. Ship industry sector contain shipbuilding, marine equipment manufacturing, ship repair or conversion and offshore structures (Othman, 2012). Regrettably, business background have largely been ignored in previous studies (Norzaidi, Chong, Murali, \& Salwani, 2009). There are a quite few of the previous studies have been conducted to investigate the relationship between demographic variables and model (Norzaidi et al., 2009). Moreover, they need to be reported in a study (Alam \& Noor, 2009).

Technology competence. Technology competence, also called technological readiness, consists of IT infrastructure and IT professionals [47] [48]. IT infrastructure refers to installed network technologies and enterprise systems, which provide a platform on which the IS / IT applications can be built (Y.-M. Wang et al., 2010). IT professionals refer to possessing the knowledge and skills to implement e-accounting related IT applications. Implementing e-accounting applications requires new IT skills, new IT components and adaptation of existing information systems. Therefore, we can expect that firms with greater technology competence are in a better position to adopt e-accounting. 
INTERNATIONAL JOURNAL OF ACADEMIC RESEARCH IN BUSINESS AND SOCIAL SCIENCES Vol. 8, No. 11, Nov, 2018, E-ISSN: 2222-6990 C 2018 HRMARS

\section{Environmental}

There are three dimensions in the environmental context which are external pressure, security and partner readiness will be defined as technology adoption determinant in this study.

External pressure. A decision to use IS / IT technology depends on the pressures exerted by other organizations that have already done so (Hassan, 2013). External pressure like pressure from business trading partners is one of the important predictor that has strong influence on adoption of ICT (Alam \& Noor, 2009). Lacking of pressure from their trading partners, the business owner may perceived the technology as a waste of resources (lacovou, Benbasat, \& Dexter, 1995) (J.Y.L. Thong \& Yap, 1995). It means that SMEs trading partners are not fully utilizing IT in doing business. Organizations use EA in response to external pressures because of the fear of being left behind, to respond to the desire of their partners in the supply chain to be connected to them via e-accounting, as well as because of written and unwritten norms

Security. Security issues, uncertainty about how to evaluate potential benefits of IS / IT, capital outlay with no guarantee of likely returns, possibility of monetary losses, laws and regulations governing e-accounting, opportunity to disclose private consumer information, and external business risks related to the communication issues with suppliers are parameters of perceived risks of IS / IT by SMEs (Ghobakhloo \& Tang, 2013). On the other hand, this advanced technology has also created significant risks related to ensuring the security and integrity of e-accounting systems (Abu-Musa, 2006). The technology, in many cases, has been developed faster than the advancement in control practices and has not been combined with similar development of the employees' knowledge, skills, awareness, and compliance. Every day, reports can be found in accounting and financial publications about computer related data errors, incorrect financial information, violation of internal controls, thefts, burglaries, fires and sabotage (Abu-Musa, 2006). Organizations should be aware with the potential security threats that might challenge their EA and implement the relevant security controls to prevent, detect and correct such security breaches.

Partner readiness. Successful implementation of IS in an organization depends on the readiness of the trading partners to facilitate the use of it (Hassan, 2013). As the use of EA requires collaboration between multiple organizations level, partner readiness becomes salient. The use of IT / IS requires trading partners to adopt compatible the systems so that they can engage in electronic interactions and transactions (Zhu, Kraemer, \& Xu, 2003). In a trading community with greater partner readiness, organizations are in a better position to use EA due to network effects. Partner readiness was found to affect IS adoption in the study by (Hassan, 2013).

\section{Owner-Manager}

This study will employ the model constructed specifically for SMEs by Thong (James \& Thong, 1999). The model suggests that due to the critical role played by owner-managers in SMEs, the 
decision-maker characteristics should be conceptualized as a main context (Rogers, 1995). There are six dimensions in the owner-manager context which are owner-manager's innovativeness and demographic factors namely age, race, gender, education level and accounting education background will be defined as technology adoption determinant in this study.

Owner-manager's Innovativeness. The CEO of SMEs or owner-manager is an entrepreneur figure who is crucial in determining the innovative attitude of a small business. This is because the CEO's qualities are the determinants of the overall management style of the business. In fact, the rate at which a small business changes depends not only on factors like business size or market forces, but also on the abilities and inclinations of the CEO and the extent to which he is able or prepared to devolve management. It is the role adopted by the CEO that determines the innovativeness of the business. In a business, the adaptor CEO would seek solutions that have already been tried and understood. On the other hand, the innovator CEO would prefer solutions that change the structure in which the problem is embedded. In other words, solutions those have not been tried out and are therefore risky. Unless the CEO has the will to innovate, there is little that other members of the business can do to expedite the adoption of IT (J.Y.L. Thong \& Yap, 1995). Likewise, another determinant of EA applications adoption attributable to the top management characteristics is CEO innovativeness. Innovative CEOs would prefer to apply distinctive and risky solutions such as IS that modify the structure in which the problems are generated (Ghobakhloo et al., 2011). Thus, CEO's desire to be more innovative will expedite the process of IS adoption ( Thong \& Yap, 1995).

Owner-manager's demographic factors. Demographic factors namely age, race, gender, education level and accounting education background are potential factors influencing the decision-maker to adopt the technologies. Unfortunately, user demographics have largely been ignored in past studies. Very few of the previous studies have been conducted to investigate the relationship between demographic variables (i.e. age, gender, background of education and position) and model (Norzaidi et al., 2009) at organizational level. Potential correlations between some of the independent variables (e.g. gender, race, education level of the manager) need to be reported in a future study (Alam \& Noor, 2009). As gender variable, Venkatesh \& Morris (Venkatesh \& Morris, 2000) disclosed that compared to women, men's technology usage decisions were more strongly influenced by their perceptions of usefulness. In contrast, women were more strongly influenced by perceptions of ease of use and subjective norm, although the effect of subjective norm diminished over time. The empirical evidence on the significant correlations between the users' demographic variables and IS/IT adoption leads into believing that the owner-managers' demographic characteristics may predict e-accounting adoption in the maritime sector. 


\section{Maritime firm performance}

SMEs accounting information system implementation and success have been extensively researched. A study conducted by Soudani [53]; Saira, Zariyawati, \& Annuar [54] discovered that SMEs adopting accounting information system show significant improvement in performance. This claim is supported by Soudani (Soudani, 2012) that AIS is very useful and have effect on organizational performance. Generally, firm performance is a difference between the total of revenue and expenses. The firm achieves high performance when revenue excess than expenses. In this condition the organization could get profit. The firms will success when they get more sales and profit. It would cover the cost and working capital. Financial performance usually measured by financial ratio for example return on asset (ROA), return on sale (ROS), the total of assets, working capital and economic value added (EVA) (Mokhtar \& Muda, 2012; Soudani, 2012). This measurement involves monetary matter. At the same time, non-financial performance is would be measured by the number of customers, suppliers, the turnover of employees and competitive advantage.

Resource-based view theory is the theory related to the firm performance. The resources of the firm include internal and external. The resources and capabilities for the technology adoption are applied in firm overall performance. The importance of the resource-based view (RBV) of strategic management is manifest in its rapid diffusion throughout the strategy literature (e.g., (Barney, 1991);(Wernerfelt, 1984)). Drawing on previous research in RBV, this study aims at illustrating the interrelationships between RBV and organizational innovation which is relates with technology innovation as AIS.

\section{METHODOLOGY}

From the literature review above, the conceptual framework (Figure 1) was developed as well as the hypothesis.

\section{Figure 1: Conceptual framework}

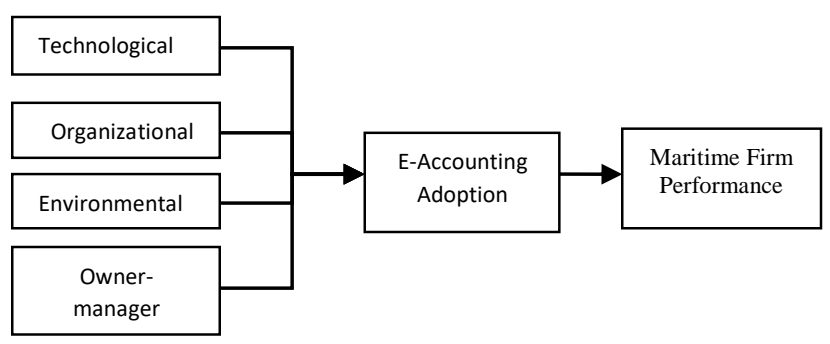


Figure 1 shows the contexts of technology, organizational, environment and owner-manager will be expected to influence the e-accounting adoption among Malaysian maritime SMEs. Each context has its own factors. The technological context has three dimensions namely relative advantage, compatibility and complexity. The organizational context will measure three factors that are financial commitment, business / maritime cluster and technology competence. For environmental context there are three dimensions which are external pressure, security and partner readiness. While in owner-manager context, there six dimensions namely ownermanager's innovativeness and demographic factors which are age, race, gender, education level and accounting education background. The e-accounting deployment will affect the maritime SMEs overall performance as a dependent variable.

For future direction of this study, a survey questionnaire will be used to collect the data from five region in Malaysia namely north area, west coast, east coast, south area and east Malaysia. The proportional stratified random sampling method will be employed. The questionnaire will be distributed to the owner-manager of SMEs maritime who adopt e-accounting. The data collected will be analyzed using structural equation model (SEM) in order to confirm the relationships. The interview session will be conducted to explain the initial result in dept. Moreover, the secondary data from maritime public listed company will triangulate the findings.

\section{CONCLUSION AND FUTURE DIRECTION}

This conceptual paper has outlined the crucial of record keeping in financial management of SMEs which will affect the overall firm performance. E-accounting is suggested as the tool to solve the poor record keeping. Previous literatures show those four contexts; technology, organization, environment and owner-manager influence the information technology adoption at firm level. As maritime industry is related to high technology industry, e-accounting adoption is seem will contribute to the firm performance in order to meet the SBSR 2020. Hence, as for this study, the conceptual framework will be used to confirm the model on the effect of e-accounting adoption on performance of Malaysian maritime industry. This framework should be further analyzed with empirical data. This future study will give an impact to the policy maker and related party as well as maritime firm where the result may reveal the factor influencing the e-accounting adoption and its impact on the firm performance of maritime industry. Further, the findings may contribute to the policy making and encouragement in e-accounting adoption.

\section{REFERENCES}

Abu-Musa, A. A. (2006). Investigating the perceived threats of computerized accounting information systems in developing countries: an empirical study on Saudi organizations. Journal of King Saud University - Computer and Information Sciences, 18, 1-30. http://doi.org/10.1016/S1319-1578(06)80001-7 
INTERNATIONAL JOURNAL OF ACADEMIC RESEARCH IN BUSINESS AND SOCIAL SCIENCES Vol. 8, No. 11, Nov, 2018, E-ISSN: 2222-6990 @ 2018 HRMARS

Ademola, I. S., O, O. S., Olusuyi, A. E., \& Edun, F. (2013). Why small scale businesses failed as a remedy to unemployment problem in Nigeria. IOSR Journal Of Humanities And Social Science (IOSR-JHSS), 8(4), 68-73.

Alam, S. S., \& Noor, M. K. M. (2009). ICT adoption in small and medium enterprises : an empirical evidence of service sectors in Malaysia. International Journal of Business and Management, 4(2), 112-125.

Ali, A., Rahman, M. S. A., \& Ismail, W. N. S. W. (2012). Predicting continuance intention to use accounting information systems among SMEs in Terengganu, Malaysia. Int. Journal of Economics and Management, 6(2), 295-320.

Amelia, Fariha, Z., \& Azliza. (2014). The usage of computerised accounting system: the case of small and medium enterprise in Malaysia. Australian Journal of Basic and Applied Sciences, 8(4), 199-205.

Amidu, M., Effah, J., \& Abor, J. (2011). E-accounting practices among small and medium enterprises in Ghana. Journal of Management Policy and Practice, 12(4), 146-155.

Barney, J. (1991). Firm resources and sustained competitive advantage. Journal of Management, 17(1), 99-120.

Bass, H. H., \& Siebert, R. E. (2007). SME in Germany's maritime industry: innovation, internationalisation and employment. International Journal of Globalisation and Small Business, 2(1), 19-33. http://doi.org/10.1504/IJGSB.2007.014185

Corrocher, N. (2003). The diffusion of internet telephony among consumers and firms current issues and future prospects. Technological Forecasting and Social Change, 70(6), 525-544. http://doi.org/10.1016/S0040-1625(02)00322-0

Evans, C., Carlon, S., \& Massey, D. (2005). Record keeping practices and tax compliance of SMEs. EJournal of Tax Research, 3(2), 228-334.

Fatoki, O. (2012). An investigation into the financial management practices of new microenterprises in South Africa. J Soc Sci, 33(2), 179-188.

Ghobakhloo, M., Arias-Aranda, D., \& Benitez-Amado, J. (2011). Adoption of e-commerce applications in SMEs. Industrial Management \& Data Systems, 111(8), 1238-1269. http://doi.org/10.1108/02635571111170785

Ghobakhloo, M., \& Tang, S. H. (2013). The role of owner/manager in adoption of electronic commerce in small businesses: The case of developing countries. Journal of Small Business and Enterprise Development, 20(4), 754-787. http://doi.org/10.1108/JSBED-12-2011-0037

Grande, E. U., Estebanez, R. P., \& Colomina, C. M. (2011). The impact of Accounting Information Systems ( AIS ) on performance measures : empirical evidence in Spanish SMEs. The International Journal of Digital Accounting Research, 11, 25-43.

http://doi.org/10.4192/1577-8517-v11

Hassan, H. (2013). Factors affecting the extent of e-procurement in small and medium enterprises in New Zealand. Massey University. 
INTERNATIONAL JOURNAL OF ACADEMIC RESEARCH IN BUSINESS AND SOCIAL SCIENCES Vol. 8, No. 11, Nov, 2018, E-ISSN: 2222-6990 @ 2018 HRMARS

Huynh, Q. L., \& Yaling, L. (2013). Mediation of computerized accounting system (CAS) adoption on relationship between environmental uncertainty and organizational performance. Journal of Modern Accounting and Auditing, 9(6), 747-755.

lacovou, C. L., Benbasat, I., \& Dexter, A. S. (1995). Electronic data interchange and small organizations: adoption and impact of technology. MIS Quarterly, 19(4), 465-485.

Ilias, A. (2013). Factor affecting the computerised accounting system (CAS) usage in public sector. Journal of Internet Banking and Commerce, 18(1), 1-29.

Ismail, N. A., \& King, M. (2005). Firm performance and AIS alignment in Malaysian SMEs. International Journal of Accounting Information Systems, 6(4), 241-259. http://doi.org/10.1016/j.accinf.2005.09.001

Ismail, N. A., \& King, M. (2007). Factors influencing the alignment of accounting information systems in small and medium sized Malaysian manufacturing firms. Journal of Information Systems and Small Business, 1(1-2), 1-20.

Ismail, W. S. W., Ali, A., \& Rashid, N. M. N. N. M. (2017). Does Adoption of CAIS differentiate the SMEs Performance: Evidence in Malaysia. World Applied Sciences Journal, 35(9), 19811985. http://doi.org/10.5829/idosi.wasj.2017.1981.1985

Malaysia Shipbuilding/Ship Repair Industry Report 2013/2014. (2013).

Malaysian Shipbuilding/Ship Repair Industry Strategic Plan 2020. (2011).

Maseko, N., \& Manyani, O. (2011). Accounting practices of SMEs in Zimbabwe: An investigative study of record keeping for performance measurement (A case study of Bindura). Journal of Accounting and Taxation, 3(8), 171-181. http://doi.org/10.5897/JAT11.031

Mokhtar, M. Z., \& Muda, M. S. (2012). Comparative study on performance measures and attributes between ISO and non-ISO certification companies. International Journal of Business and Management, 7(3), 185-193. http://doi.org/10.5539/ijbm.v7n3p185

Muchira, B. W. (2012). Record keeping and growth of micro and small enterprises, a case study of Thika Municipality in Kenya. Kenyatta University, Kenya.

Mwakujonga, J., \& Bwana, K. M. (2013). The practice of preparing and using financial information in financial decisions : a survey of SMEs in Tanzania. European Journal of Business and Management, 5(9), 161-169.

Noronha, M. R., \& Kulkarni, A. R. (2012). E-Accounting in India. Indian Journal of Accounting, $X L I /(2), 1-10$.

Norzaidi, M. D., Chong, S. C., Murali, R., \& Salwani, M. I. (2009). Towards a holistic model in investigating the effects of intranet usage on managerial performance: a study on Malaysian port industry. Maritime Policy \& Management, 36(3), 269-289. http://doi.org/10.1080/03088830902861235

Oliveira, T., \& Martins, M. F. (2011). Literature review of information technology adoption models at firm level. The Electronic Journal Information Systems Evaluation, 14(1), 110- 
INTERNATIONAL JOURNAL OF ACADEMIC RESEARCH IN BUSINESS AND SOCIAL SCIENCES Vol. 8, No. 11, Nov, 2018, E-ISSN: 2222-6990 @ 2018 HRMARS

121.

Othman, M. R. (2012). A new management structure for Malaysian Economic Exclusive Zone. The International Journal of Social Sciences, 4(1), 47-63.

Othman, M. R., Bruce, G. J., \& Hamid, S. A. (2011). The strength of Malaysian maritime cluster: The development of maritime policy. Ocean \& Coastal Management, 54(8), 557-568. http://doi.org/10.1016/j.ocecoaman.2011.02.004

Relhan, A. (2013). E-accounting practices of SME in India. International Journal of Technical Research(IJTR), 2(1), 1-10.

Rogers, E. M. (1983). Diffusion of innovations (3rd ed.). New York: The Free Press.

Rogers, E. M. (1995). Diffusion of innovations (4th ed.). New York: The Free Press.

Saira, K., Zariyawati, M. A., \& Annuar, M. N. (2010). Information system and firms' performance: The case of Malaysian small medium enterprises. International Business Research, 3, P28.

Sam, M. F. M., Hoshino, Y., \& Tahir, M. N. H. (2012). The adoption of computerized accounting system in small medium enterprises in Melaka, Malaysia. International Journal of Business and Management, 7(18), 12-25. http://doi.org/10.5539/ijbm.v7n18p12

Samujh, R.-H., Twiname, L., \& Reutemann, J. (2012). Credit guarantee schemes supporting small enterprise development : a review. Asian Journal of Business and Accounting, 5(2), 21-40.

SME Annual Report 2012/2013. (2013).

Soudani, S. N. (2012). The usefulness of an accounting information system for effective organizational performance. International Journal of Economics and Finance, 4(5), 136145. http://doi.org/10.5539/ijef.v4n5p136

Soudani, S. N. (2013). The impact of implementation of e-accounting system on financial performance with effects of internal control systems. Research Journal of Finance and Accounting, 4(11), 17-28.

Stefanou, C. J. (2006). The complexity and the research area of AIS. Journal of Enterprise Information Management, 19(1), 9-12. http://doi.org/10.1108/17410390610636841

Tavakolian, H. (1995). Pc-based financial software: emerging options. Industrial Management \& Data Systems, 18(12), 41-53. http://doi.org/10.1108/eb028433

Thong, J. Y. . L. (1999). An intergrated model of information systems adoption in small businesses. Journal of Management Information Systems, 15(4), 187-214.

Thong, J. Y. L., \& Yap, C. S. (1995). CEO characteristics, organizational characteristics and information technology adoption in small businesses. Omega, 23(4), 429-442. http://doi.org/10.1016/0305-0483(95)00017-I

Tijani, O. M., \& Mohammed, A. K. (2013). Computer-based accounting systems in small and medium enterprises : empirical evidence from a randomized trial in Nigeria. Universal Journal of Management, 1(1), 13-21. http://doi.org/10.13189/ujm.2013.010103 
INTERNATIONAL JOURNAL OF ACADEMIC RESEARCH IN BUSINESS AND SOCIAL SCIENCES Vol. 8, No. 11, Nov, 2018, E-ISSN: 2222-6990 C 2018 HRMARS

Tornatzky, L. G., \& Fleischer, M. (1990). The process of technology innovation. Lexington: Lexington Books.

Tornatzky, L. G., \& Klein, K. J. (1982). Innovation characteristics and innovation adoptionimplementation: a meta-analysis of findings. IEEE Transactions on Engineering Mangement, EM-29(1), 28-43.

Velankar, N., Gupta, R. C., \& Garud, U. (2013). E-Accounting practices among SMEs: a study of M.P. Region. Journal of Management Value \& Ethics, 3(3), 94-106.

Venkatesh, V., \& Morris, M. G. (2000). Why don't men ever stop to ask for directions? Gender, social influence, and their role in technology acceptance and usage behavior. MIS Quarterly, 24(1), 115-139.

Wan Ismail, W. N. S. (2014). Adoption of computerized information system (CAIS) among Malaysian SMEs. University Malaysia Terengganu.

Wang, D. H.-M., \& Huynh, Q. L. (2013). Effects of environmental uncertainty on computerized accounting system adoption and firm performance. International Journal of Humanities and Applied Sciences (IJHAS), 2(1), 13-21.

Wang, Y.-M., Wang, Y.-S., \& Yang, Y.-F. (2010). Understanding the determinants of RFID adoption in the manufacturing industry. Technological Forecasting and Social Change, 77(5), 803-815. http://doi.org/10.1016/j.techfore.2010.03.006

Wernerfelt, B. (1984). A resource-based view of the firm. Strategic Management Journal, 5, 171-180. http://doi.org/10.1002/smj.4250050207

Zhu, K., Dong, S., Xu, S. X., \& Hally, M. (2006). Innovation diffusion in global contexts: determinants of post-adoption digital transformation of European companies. European Journal of Information Systems, 15(6), 601-616. http://doi.org/10.1057/palgrave.ejis.3000650

Zhu, K., Kraemer, kenneth L., \& Xu, S. (2003). Electronic business adoption by European firms: a cross- country assessment of the facilitators and inhibitors. European Journal of Information Systems, 12(4), 251-268.

Zhu, K., Kraemer, K. L., \& Xu, S. (2006). The process of innovation assimilation by firms in different countries: a technology diffusion perspective on e-business. Management Science, 52(10), 1557-1576. http://doi.org/10.1287/mnsc.1050.0487 